\title{
EVALUATION THE IMPACT OF CATCHMENT'S SPATIAL DEVELOPMENT ON RUNOFF USING SPR INDEX
}

\author{
Joanna Szajnar, Wiesław Gądek ${ }^{\bowtie}$ \\ Faculty of Environmental and Power Engineering, Cracow University of Technology, Warszawska 24, 31-155 Kraków
}

\begin{abstract}
Objective of the work

The objective of this publication is to evaluate the impact of forest areas and urbanized areas on process of river runoff over the years, along with an analysis of the development of hydrographs in selected catchments for the upper Vistula (Wisła) region.
\end{abstract}

\begin{abstract}
Material and methods
For the purpose of the present analyses, the following data were used: vector data from the Computer Database of the Hydrographic Division Map of Poland (MPHP), 2010 on the scale of 1:50000 obtained from the National Water Management Authority (MPHP, 2019); hydrological data from the database of the Institute of Meteorology and Water Management (PIB), namely daily flow values in 4 water gauge cross-sections located on the Bystra, Wisła, Wieprzówka and Biała rivers for the measurement period 1981-2017 (IMGW PIB, 2019); meteorological data from the database of the Institute of Meteorology and Water Management of the National Research Institute including daily sums of precipitation for the stations: Kamesznica, Wisła Malinka, Wadowice, Gierałtowice, Straconka, Szczyrk and Mazańcowice for the period 1981-2017 (IMGW PIB, 2019); data on land development and land use in the catchment area, that is, vector data from CLC1990 and CLC2012 databases on the scale of 1:100000 (CLC, 2019). The maximum hydrographs recorded in 1991 and 2010 were subjected to detailed analysis. The recorded discharge hydrographs were transformed into the unified format of the hydrographs proposed by Archer (Archer et al., 2000; Gądek, 2017). Based on the data, the SPR (standard percentage runoff) index was determined and the formula for calculating the SPR index based on the BFI base flow index was evaluated.
\end{abstract}

\section{Results and conclusions}

The obtained results are presented in the figures and tables. The analyses did not show the impact of forested and impervious surfaces on the runoff from the catchment. The adopted SPR index proved to be ineffective as impact indicator. In addition, determining the value of this index is very difficult and it requires well-functioning hydro-meteorological monitoring system.

Keywords: SPR, BFI, hydrograph width $\mathrm{W}_{50}$, forest cover index, degree of urbanisation (land development index)

\section{INTRODUCTION}

Runoff from the river catchment depends on the geological structure of the catchment, topography, duration and intensity of precipitation, spatial development of the catchment area and land use within it, as well as human activity changing the natural nature of land cover (Gudowicz and Zwoliński, 2017). Anthropological pressure associated with the intensification of industrial production, development of river valleys

凶e-mail:wieslaw.gadek@iigw.pk.edu.pl 
and mountain streams, leads to a decrease in natural retention and an increase in losses caused by floods at lower peak discharge values (Zevenbergen et. al., 2011; Więzik, 1997). In the spatial development of the catchment, the runoff is mainly determined by impervious surfaces and natural ecosystems. The most frequently taken into account is the percentage share of the impervious surface area (developed land) and the share of forests, respectively referred to as urbanization and forest cover indices.

Forest is defined as a permanent and complex terrestrial ecosystem comprising soil cover together with plants and animals, forming a specific biosphere (Osuch and Kowalik, 1998). The relationship between forest and water plays a special role in shaping the runoff from the catchment. Next to the trees themselves, a significant role in capturing rainwater is played by the understory layer, shrubs, undergrowth, litter, as well as moss (Osuch and Kowalik, 1998). Field tests provide the percentage share of interception values for individual components constituting the forest ecosystem, depending on the type of forest and specific features such as: height, age, species composition of the stand (Osuch and Kowalik, 1998). The forest is often called the "water reservoir", whose main dimensions are the surface and height of the retained water layer (Osuch and Kowalik, 1998; Rozwałka and Wiśniewski, 1998). With the help of appropriate mathematical models, it is possible to assess the impact of the forest on water management in the catchment, as well as the development of the hydrograph for a specific event of torrential precipitation. As a result, it is possible to determine the effects of deforestation on water regime and hydrographic conditions, including in particular the shaping of runoff from the catchment (Osuch and Kowalik, 1998; Osuch et al., 2009).

Forest management is focused on water-regime regulating ecosystems. In particular, threats to these ecosystems began to be analysed, including deforestation, forest dieback, as well as changes to the species composition of the stand. This phenomenon was particularly evident in the nineteenth and early twentieth centuries, when significant deforestation took place (Pieńkos and Szujecki, 1998). During this period, approximately 860 million hectares of forests were transformed into agricultural areas (Pieńkos and Szujecki, 1998). In the 1980 s, a particularly notice- able phenomenon was regional forest dieback, caused by air pollution with compounds of sulphur, nitrogen, ozone, and "acid rain" (Pieńkos and Szujecki, 1998).

Already at the end of the 1950s, the beginning of the phenomenon of dieback of Żywiec mountain spruces was observed, and that was directly influenced by the introduction of spruce monocultures replacing natural Carpathian beech (Ministry of the Environment, 2009). Maintenance of sanitary regimes saved these areas from the phenomenon occurring on a large scale. In the following decades, decay of spruce trees was observed, progressing from west to east, the main reason for which was the increasing level of industrial emissions. The fastest actions in the reconstruction of stands were taken in the forest districts most exposed to industrial emissions in this region: Andrychów, Bielsko, and Ustron. In the remaining forest districts of the Beskid region - namely: Sucha, Jeleśnia, Wisła, Węgierska Górka, and Ujsołów - the reconstruction began later, which resulted in a persistently high share of the spruce species in this area (Ministry of the Environment, 2009).

Pest outbreaks have become another cause of the dieback of spruces in the Beskid region. In the years 1982-1985 in the highest formations of the Silesian Beskids and Żywiecki there was a gradation of web-spinning sawfly (Cephalcia falleni), while in the years 1977-1985, in the forest inspectorates: Jeleśnia, Węgierska Górka and Ujsoły there was a gradual appearance of the larch tortrix (Zeiraphera griseana) (Ministry of the Environment, 2009). Another threat is recurring spruce web-spinning sawfly (Cephalcia abietis) recurring in cycles of 3 to 5 years, and locally occurring little spruce sawfly (Pristiphora abietina (Christ.)).

The adverse situation is further compounded by negative changes in soil properties. Research on soil chemistry above all indicates a decrease in its acidity, in organic and natural levels, to below $\mathrm{pH} 3.0$, and a high concentration of toxic aluminium compounds, which lead to disturbances in spruce physiology, reducing its resistance to pest infestation. Since 2006, a particularly dangerous and large-scale phenomenon of the dieback of spruce stands due to adverse weather conditions has been observed. Record high temperatures and a prolonged period of drought favoured the development of pests. The root system 
was infected by the genus of honey fungi (Armillaria Staude). Forced sanitary cuts also occur as a result of wind and snow damage. In 2004, large-scale wind damage occurred in the Beskidy mountain forests, as a result of which a total of 243 thousand $\mathrm{m}^{3}$ of fallen and broken trees had been inventoried (Ministry of the Environment, 2009).

The goal of the present publication is to assess the impact of forest areas and developed areas on the course of river runoff over the years, along with an analysis of the course of hydrographs in selected catchments within the upper Vistula (Wisła) region.

The research was conducted using data from four water gauge cross-sections observed by the Institute of Meteorology and Water Management of the PIB National Research Institute, from the period 1981-2017. Land development data were obtained from Corine Land Cover (CLC). Based on that, forest cover and urbanization indices were determined (Mills et al., 2014; Murphy et al., 2014; O'Connor et al., 2014). CLC is a database system implemented by the European Environment Agency, whose purpose is to provide current information on land use and land development (Bossard et al., 2000; Bielecka, Ciołkosz, 2004; Bossard et. al., 2000). The main source of data for the reference year 1990 (CLC, 1990) are satellite images from the Landsat 4/5 TM satellite, while in the case of CLC2012, it is the images from the satellites SPOT4/5, IRS-P6 and RapidEye (CLC, 2019). Land cover data is obtained on three levels (CLC, 2019; Lewiński, 2007). The first level includes five main categories of land cover, i.e. anthropogenic areas, agricultural areas, forest and semi-natural areas, wetlands, and water bodies (CLC, 2019). At the second level, 15 forms of land cover were distinguished, while at the third level, 44 forms were distinguished - this being the most detailed information level (CLC, 2019). In the case of Poland, the land cover database contains 5 main forms considered as the first level, 15 subgroups of the second level, and 31 forms of the land cover of the third level (CLC, 2019).

The forest category is defined as the area occupied by trees with a minimum height of $5 \mathrm{~m}$ and a tree crown cover of at least 30\% (Bossard et al., 2000). The second level categories consist in the subdivision into deciduous forests, coniferous forests and mixed forests. Deciduous and coniferous forests are formations composed mainly of trees, as well as thickets and bushes. Mixed forests are plant formations of deciduous and coniferous forests, presenting an almost equal degree of mixing (CLC, 2019). The classification of anthropogenic areas includes builtup areas, used for residential, commercial and industrial purposes, as well as mining areas, and urban green areas (CLC, 2019). Urban areas constituting anthropogenic areas, in the case of the studied catchments, constitute primarily urban development and industrial areas.

\section{DESCRIPTION OF THE STUDIED AREA AND THE DATA}

In order to conduct a comparative analysis regarding the possible impact of forest areas and urbanized areas on the shaping of runoff from the catchment, including the parameters of individual freshet hydrographs, four research areas were selected. These were the catchments of: the Biała river to the Czechowice-Bestwina water-gauge cross-section, the Wieprzówka river to the Rudze cross-section, the Wisła (Vistula) river to the Wisła cross-section, and the Bystra river to the Kamesznica cross-section (see: Fig. 1). In terms of administration, the Wieprzówka river catchment area is located in the Małopolska region, while the other three catchments in the Ślaskie (Silesia) region. In relation to regions according to the physico-geographical division of Poland, these catchments cover the area of the Outer Western Carpathians. The Bystra and Wisła rivers are montane catchments, located in the macro-region of the Beskidy Zachodnie (Western Beskidy). Both catchments belong to the Beskid Śląski (Silesian Beskid) mesoregion. The water catchment area of the Wieprzówka river and the Biała river are located within the macro-regions of: Beskidy Zachodnie (Western Beskidy) and Pogórze Zachodnie (Western Foothills). The Wieprzówka catchment belongs to the Dolina Górnej Wisły (Upper Vistula Valley) mesoregion, and the Biała catchment to the Wyżyna Katowicka (Katowice Upland) mesoregion (Kondracki, 2000).

Basic data on the surface area of selected catchments, river network density factor, and average slope $\mathrm{S}_{1085}$ were developed based on vector data from the computer database of the Hydrographic Division Map of Poland MPHP, 2010 (see: Table 1) (MPHP, 2010). 

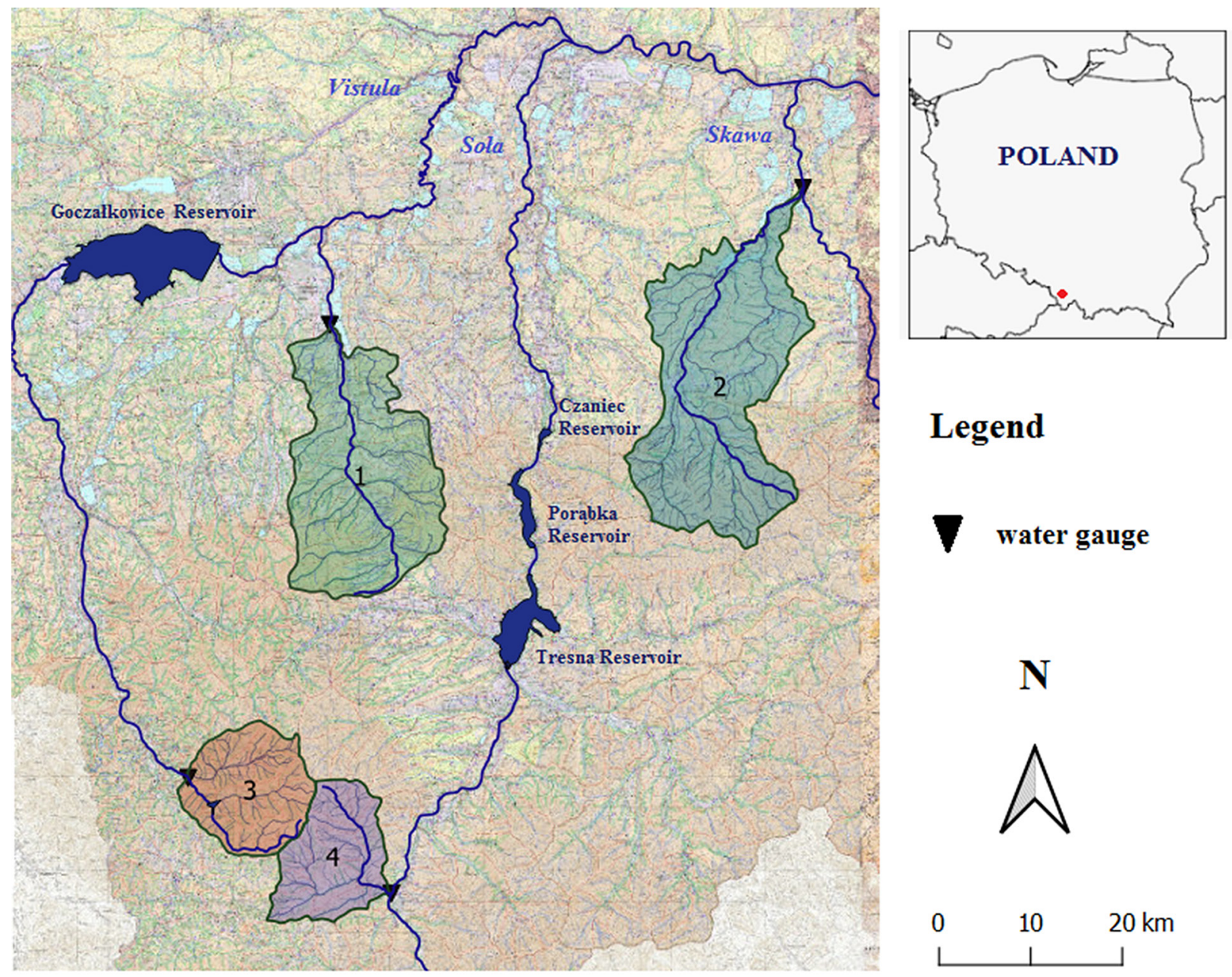

\section{Legend}

7 water gauge

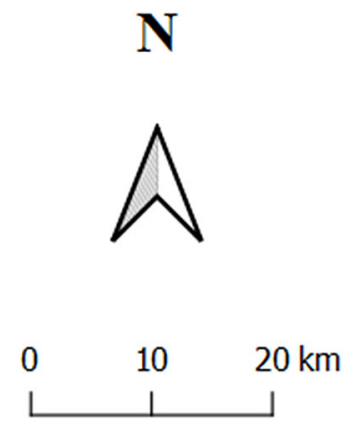

Fig. 1. Location of the studied catchments according to the numbering in Table 1

Table 1. Basic parameters of the studied catchments

\begin{tabular}{lllcccc}
\hline No. & \multicolumn{1}{c}{ River } & Gauge & $\begin{array}{c}\text { Surface area of } \\
\text { selected catchments } \\
{\left[\mathrm{km}^{2}\right]}\end{array}$ & $\begin{array}{c}\text { River network } \\
\text { density } \\
{\left[\mathrm{km}^{2} / \mathrm{km}^{2}\right]}\end{array}$ & $\begin{array}{c}\text { Slope } \mathrm{S}_{1085} \\
{[\mathrm{~m} / \mathrm{km}]}\end{array}$ & $\begin{array}{c}\text { Spring location } \\
\text { height } \\
{[\mathrm{MASL}]}\end{array}$ \\
\hline 1 & Biała & Czechowice Bestwina & 117.96 & 1.95 & 8.59 & 512 \\
\hline 2 & Wieprzówka & Rudze & 151.63 & 2.02 & 8.48 & 830 \\
\hline 3 & Wisła & Wisła & 54.59 & 1.96 & 50.83 & 1150 \\
\hline 4 & Bystra & Kamesznica & 48.18 & 2.08 & 36.78 & 1200 \\
\hline
\end{tabular}

Using CLC1990 and CLC2012, we developed the data on forest area catchment land cover and the area defined as urbanized. Both in terms of sealed (urbanized) areas and forest areas, no significant changes were recorded in the analysed catchments during the reference years 1990-2012. The changes recorded remain within the range of $1-3 \%$ and an upward trend has been observed. 
The Biała river catchment represents an urbanized catchment with a sealed (impervious) area exceeding $30 \%$. The percentage share of forest area is smaller than the share of sealed area. The share of forests in the Wieprzówka river catchment is at a similar level to the Biała river catchment. The built-up area of this catchment in the analysed period increased from $7 \%$ to $10 \%$, which gives a relative increase in soil sealing of over $40 \%$.

The Wisła river catchment, up to the Wisła water-gauge cross-section, is mostly covered with forest, while the built-up development covers only $3 \%$ of the area, and shows no upward trends. The forest cover index of the Bystra river catchment is high, but its value is lower (by $20 \%$ ) than the highest forest cover index observed for the Wisła river basin. The built-up area exceeds $5 \%$ and increases from $6 \%$ to $7 \%$ in the analysed period.

Precipitation levels have been developed on the basis of data from the period 1981-2017 recorded at the IMGW PIB meteorological stations: Wisła-Malinka, Kamesznica, Wadowice, Gierałtowice, Straconka, Mazańcowice and Szczyrk, assuming the representativeness of individual stations in all precipitation levels. Area average annual precipitation for of all water-gauge cross-sections was developed using precipitation height and the method of equal rainfall magnitude (Thiessen polygons), and the annual values are presented in Table 3. Due to the lack of data since 2014 for the Gierałtowice meteorological station, the area average annual precipitation for the Wieprzówka river catchment was calculated without that particular station. Location heights of the particular rainfall stations are shown in Table 2.

Table 2. Location heights of individual meteorological stations

\begin{tabular}{clc}
\hline No. & Meteorological station & Location height [MASL] \\
\hline 1 & Kamesznica & 500 \\
\hline 2 & Wisła-Malinka & 685 \\
\hline 3 & Wadowice & 260 \\
\hline 4 & Gierałtowice & 285 \\
\hline 5 & Straconka & 150 \\
\hline 6 & Szczyrk & 520 \\
\hline 7 & Mazańcowice & 300 \\
\hline
\end{tabular}

During data processing, it was noted that the Wisła river basin to the Wisła water gauge in 1991 had a very high rainfall, clearly higher than in other catchments.

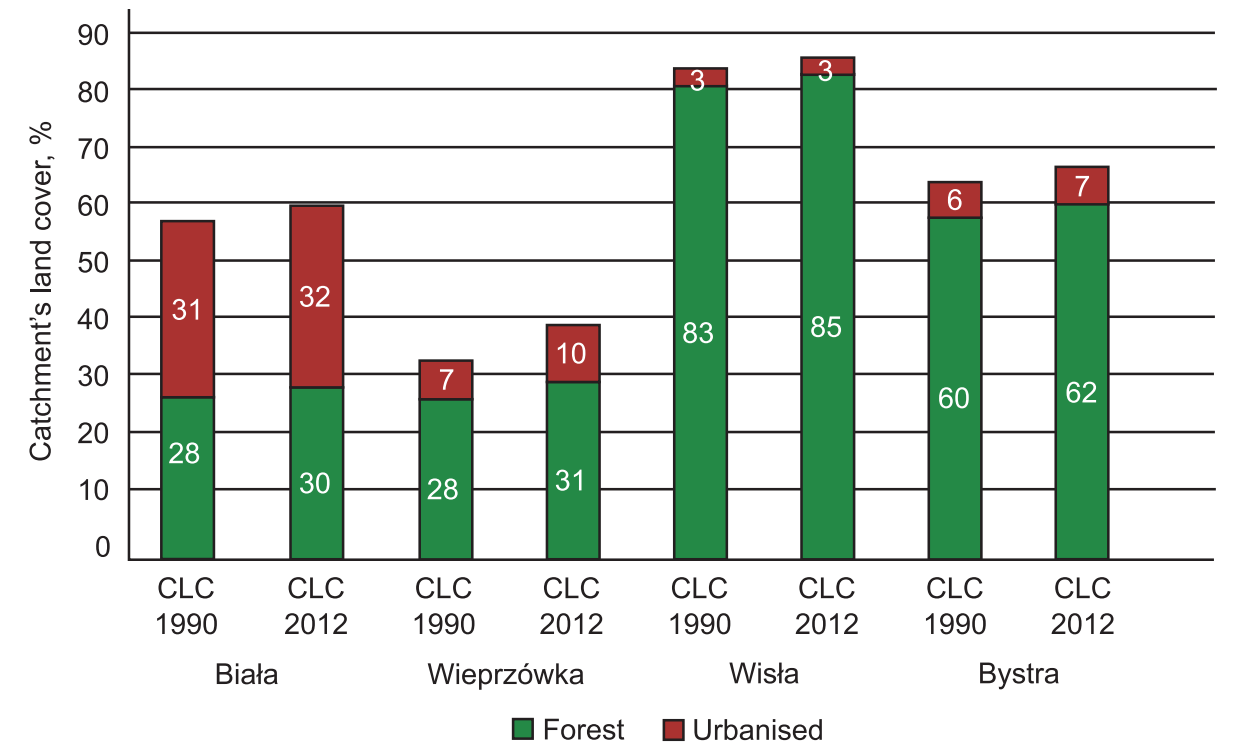

Fig. 2. Share of forest area and urbanised area in the studied catchments for two selected periods of 1990 and 2012 


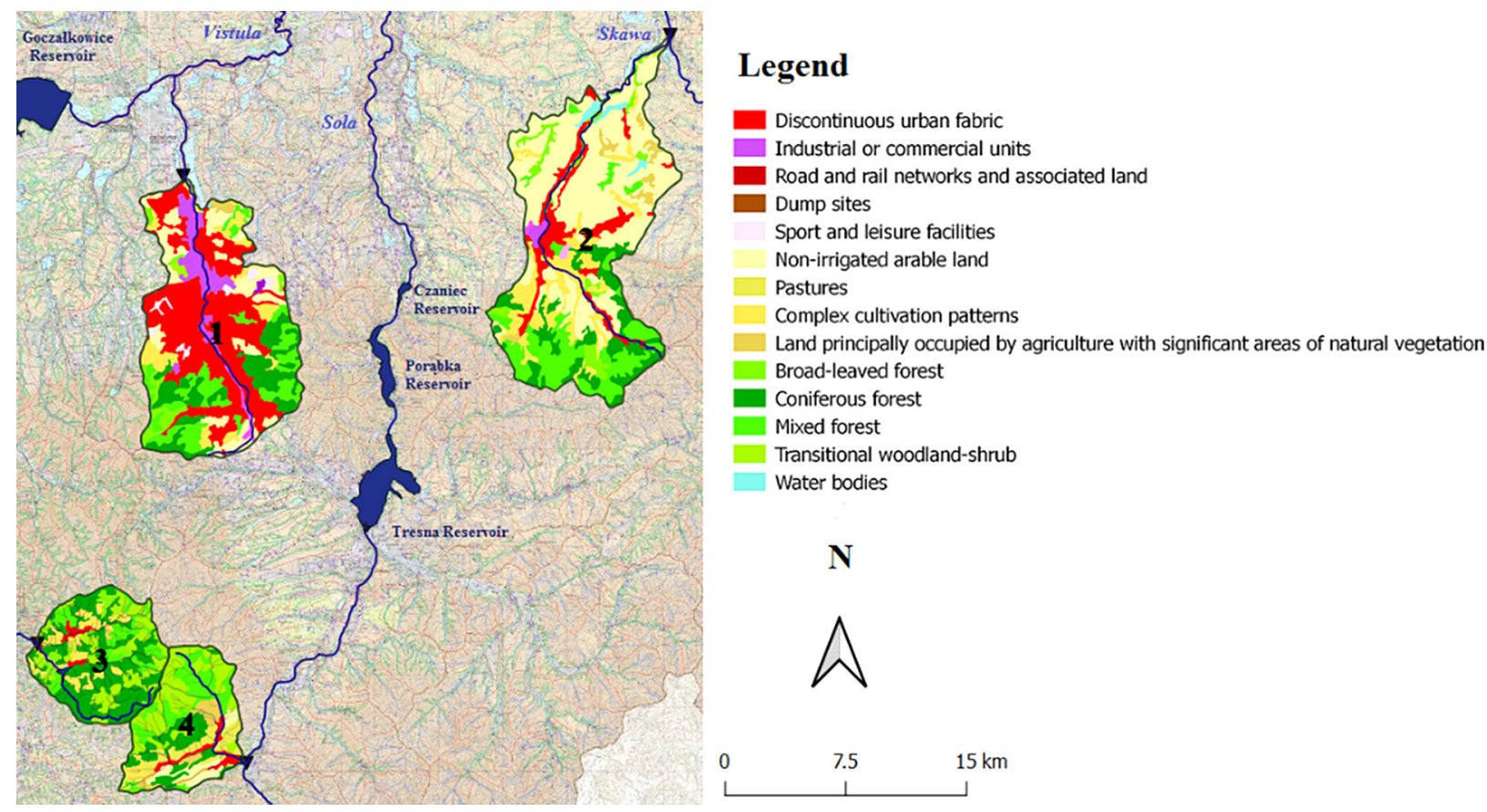

Fig. 3. Land use and land cover in selected catchment areas according to CLC 2012

The characteristic shape of the hydrograph is further compounded by high amounts of daily precipitation in this catchment lasting for several days. The highest daily rainfall occurred on August 4 reaching $82.5 \mathrm{~mm}$, the day after it amounted to $53.1 \mathrm{~mm}$, then on August 6 it fell by $29 \mathrm{~mm}$, and on August 7 it increased, again, by $41 \mathrm{~mm}$ compared to the previous day.

The forest cover development index was determined for the investigated catchments (Lambor, 1965; Ozga-Zielińska and Brzeziński, 1997). It is based on the diagram describing the change in forest cover index (percentage share of forest area in the catchment area) along with the increase in the catchment surface area. The forest cover development index is calculated using formula (1) and its values are given in Table 3:

$$
l_{r}=\frac{A_{l}}{A_{c}}
$$

where:

$A_{1}$ - surface area included under the forest cover curve $\left[\mathrm{km}^{2} \%\right]$;

$A_{c}$ - area of a rectangle with a base equal to the catchment area (A) and a height equal to $100 \%\left[\mathrm{~km}^{2} \%\right]$
Table 3. The forest cover development index for the studied river catchments, determined according to CLC1990 and CLC 2012

\begin{tabular}{lllll}
\hline & & & \multicolumn{2}{c}{$\begin{array}{c}\text { Forest cover } \\
\text { No. }\end{array}$} \\
& River & $\begin{array}{l}\text { Water-gauge } \\
\text { cross-section }\end{array}$ & \multicolumn{2}{c}{$l_{r}[-]$} \\
\cline { 3 - 5 } & & & CLC1990 & CLC2012 \\
\hline 1 & Biała & $\begin{array}{l}\text { Czechowice } \\
\text { Bestwina }\end{array}$ & 0.411 & 0.429 \\
\hline 2 & Wieprzówka & Rudze & 0.464 & 0.496 \\
\hline 3 & Wisła & Wisła & 0.828 & 0.824 \\
\hline 4 & Bystra & Kamesznica & 0.676 & 0.691 \\
\hline
\end{tabular}

In the analysed period, according to CLC1990 and CLC2012 data, the forest cover development index $l_{r}$ increases similarly to the forest cover index, except for the Wisła river catchment to the Wisła water gauge, where there was a slight decrease in this indicator. 
Table 4. Area annual precipitation totals in the period of 1981-2017 for water-gauge cross-sections of the analysed catchments

\begin{tabular}{lllc}
\hline No. & River & $\begin{array}{c}\text { Water-gauge } \\
\text { cross-section }\end{array}$ & $\begin{array}{c}\text { Area annual } \\
\text { precipitation } \\
{[\mathrm{mm}]}\end{array}$ \\
\hline 1 & Biała & $\begin{array}{l}\text { Czechowice } \\
\text { Bestwina }\end{array}$ & 1083 \\
\hline 2 & Wieprzówka & Rudze & 1172 \\
\hline 3 & Wisła & Wisła & 1396 \\
\hline 4 & Bystra & Kamesznica & 888 \\
\hline
\end{tabular}

\section{MATERIALS AND METHODS}

For the purposes of the analyses, the following were used:

- vector data from the Computer Database of the Hydrographic Division Map of Poland - MPHP, 2010 on a scale of $1: 50,000$ obtained from the $\mathrm{Na}-$ tional Water Management Board (MPHP, 2019);

- hydrological data - database of the Institute of Meteorology and Water Management PIB (daily flow values) in 4 water gauge cross-sections located on the Bystra, Wisła, Wieprzówka and Biała rivers for the measuring period 1981-2017 (IMGW PIB, 2019);

- meteorological data - the database of the Institute of Meteorology and Water Management of the National Research Institute including daily sums of precipitation for the stations: Kamesznica, Wisła-Malinka, Wadowice, Gierałtowice, Straconka, Szczyrk and Mazańcowice for the period 1981-2017 (IMGW PIB, 2019),

- land development and land use of the catchment area - vector data from CLC1990 and CLC2012 databases on a scale of $1: 100,000$ (CLC, 2019).

The maximum hydrographs recorded in 1991 and 2010 were subjected to detailed analysis. The registered flow hydrographs were transformed into the unified form of the hydrograph proposed by Archer (Archer et al., 2000; Gądek, 2017). This unification consists in presenting the hydrograph not in the form of changes in flow over time, but as a change in the flow duration curve (see: Fig. 4) (Gądek et al., 2017). This hydrograph presents the rising limb of the hy- drograph and the falling limb independently (Gądek, 2012; Gądek et al., 2017). The time for the flow increase limbs of the hydrograph is expressed in negative values, and for the flow falling limb, in positive values. The coordinate system begins at the maximum flow (Gądek, Środula; 2014). For comparative purposes, the unification of the flow to the value range from 0 to $100 \%$ is used. For the moment $t=0$, the value of $q=100 \%\left(Q_{\max }\right)$ (Gądek, 2014; Gądek, 2015). Individual flow values represent a percentage share of the flow in relation to the maximum flow (Gądek, 2014; Gądek, 2015; Gądek and Tokarczyk, 2015). Due to the fact that the flow beginning and ending the total hydrograph is greater than 0 , the flow values of $\mathrm{q}$ are greater than 0 . A sample unified hydrograph of flow duration shown in Figure 4.

$$
q=\frac{Q}{Q_{\max }} 100 \%
$$

Based on the established flow hydrograph, the hydrograph width $W_{50}$ and $W_{75}$ are determined, which allow calculating the $S P R-W_{50}$ and $S P R-W_{75}$ indicators. The hydrograph width $W_{q}$ determines the flow duration curve in hours with a probability $q$. The flow rate marker $W_{50}$ means the duration of the flow $q=50 \%$, and $\mathrm{W}_{75}$ for $q=75 \%$ (Gądek et al., 2017). $S P R-W_{50}$ is the quotient of the hydrograph volume above the

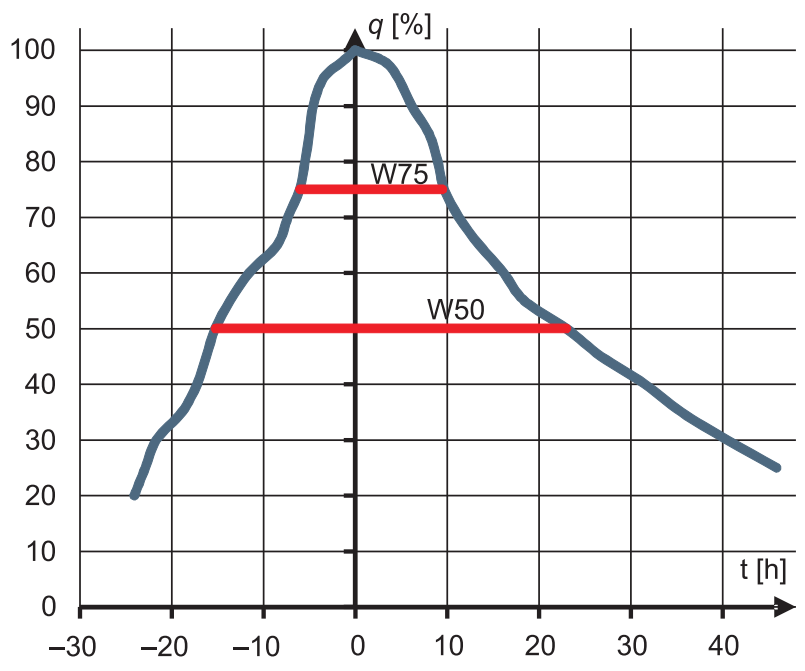

Fig. 4. Sample unified hydrograph developed according to Archer's principles for a single flood wave 
$W_{50}$ hydrograph width to the total sum of precipitation height that caused the flood, and $S P R-W_{75}$ is the quotient of the hydrograph volume above the $W_{75}$ hydrograph width to the sum of precipitation height. $S P R-W_{75}$ and $S P R-W_{50}$ are analogous to the runoff coefficient c for areas of the hydrograph above the $W_{75}$ and $W_{50}$, respectively.

\section{CALCULATION RESULTS}

The annual runoff from the catchment area and the annual precipitation totals for the analysed catchment areas from 1981-2017 are presented in Figure 5. The lack of data for the Bystra river catchment in the Kamesznica cross-section prevented the calculation of the runoff for the hydrological years 1986 and 2005-2007. Based on the available data, the SPR percentage runoff standard (Boorman et al., 1995) was determined:

$$
S P R=\frac{H}{P} \cdot 100 \%
$$

where:

$$
\begin{aligned}
& H-\text { total annual runoff from the catchment area } \\
& \quad[\mathrm{mm}] \\
& P-\text { annual sum of area precipitation height }[\mathrm{mm}]
\end{aligned}
$$

The annual runoff from the catchment and the annual totals of precipitation have been calculated in the calendar year system, i.e. from January 1 to December 31 .

The annual variability of the SPR indicator in the 1981-2017 period has been presented in Figure 6 .

The values of the SPR indicator for the Biała and Bystra river catchments are abnormally high, and additionally the runoff is at the level of precipitation supply.

SPR values should not exceed $72 \%$ as stated in the formula (4). However, studies (Boorman et al., 1995) have shown that they can range between 3.8 to $77.5 \%$ (Boorman et al., 1995). It is difficult to explain the situation, most likely it is the result of the insufficient number of precipitation height measurement stations.

The SPR was calculated based on the formula (Boorman et al., 1995):

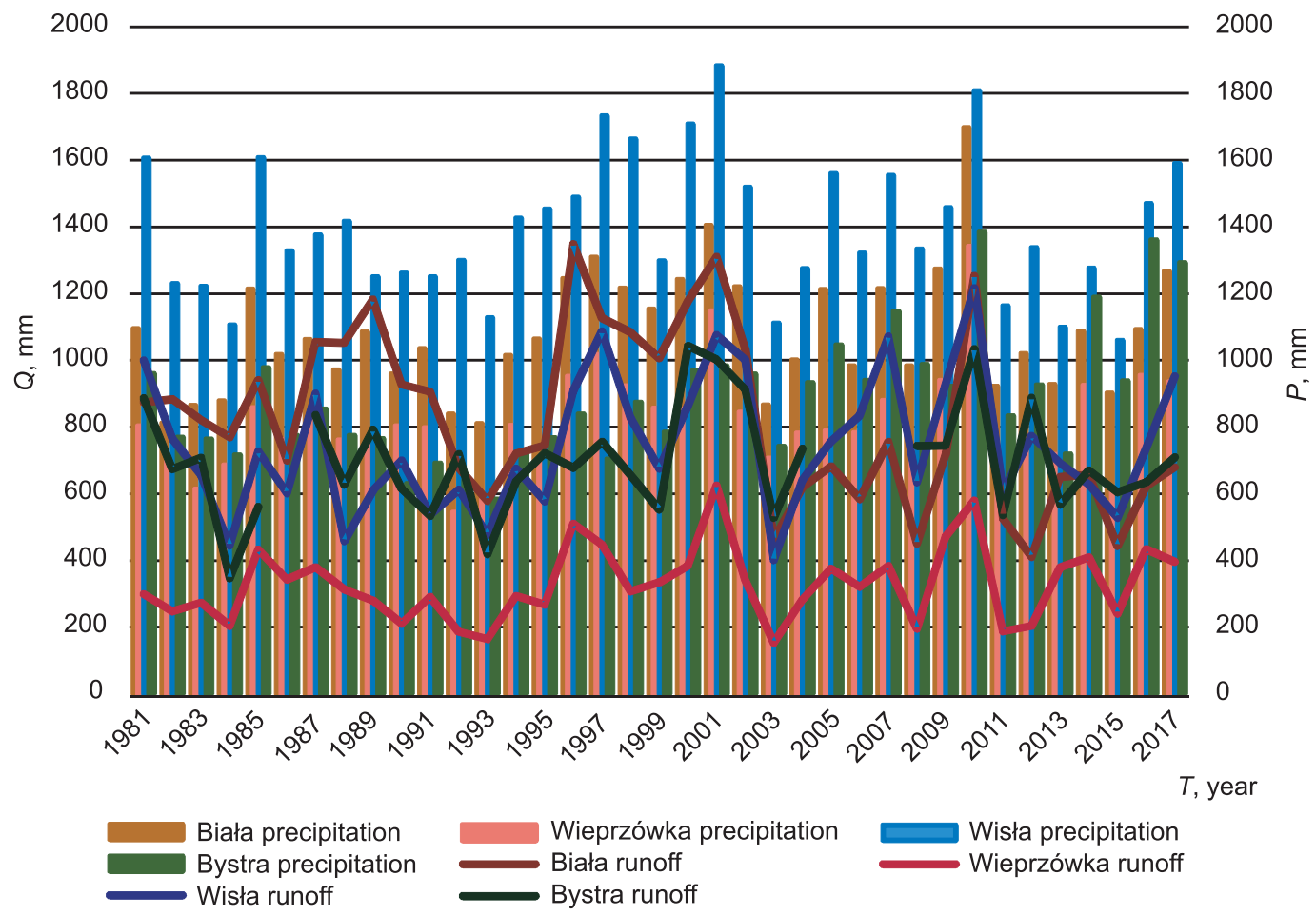

Fig. 5. Annual precipitation totals $P[\mathrm{~mm}]$ and annual runoff $\mathrm{H}[\mathrm{mm}]$ from the analysed catchments in the period 1981-2017 


$$
\mathrm{SPR}=72.0-66.5 \mathrm{BFI}[\%]
$$

where:

BFI - base flow index [-].

The physical descriptor of the catchment (BFI) was determined using the FREND algorithm, developed as part of the UNESCO International Hydrological Program for rivers throughout Europe (FREND, 1989;
Bayliss, 1999). It is given as a dimensionless quantity between 0 and 1.0.

The research experiment carried out for the Wieprzówka river catchment (see: Fig. 7) showed that the calculated SPR values according to the formula (4) differ from those calculated according to formula (3). The proposed formula (4) is not satisfactory.

When analysing the highest annual precipitation sums, in the studied period, we observe that they occur

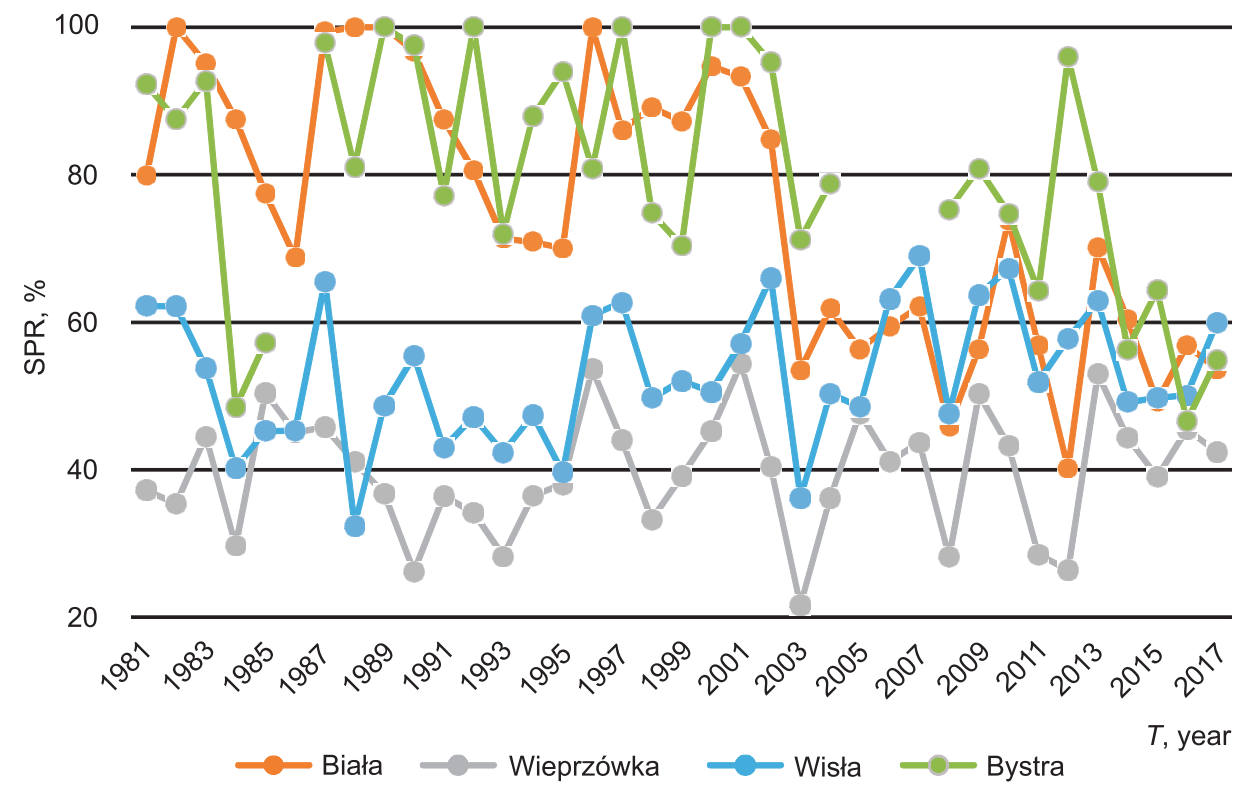

Fig. 6. Values of SPR indicator for the analysed catchments in 1981-2017

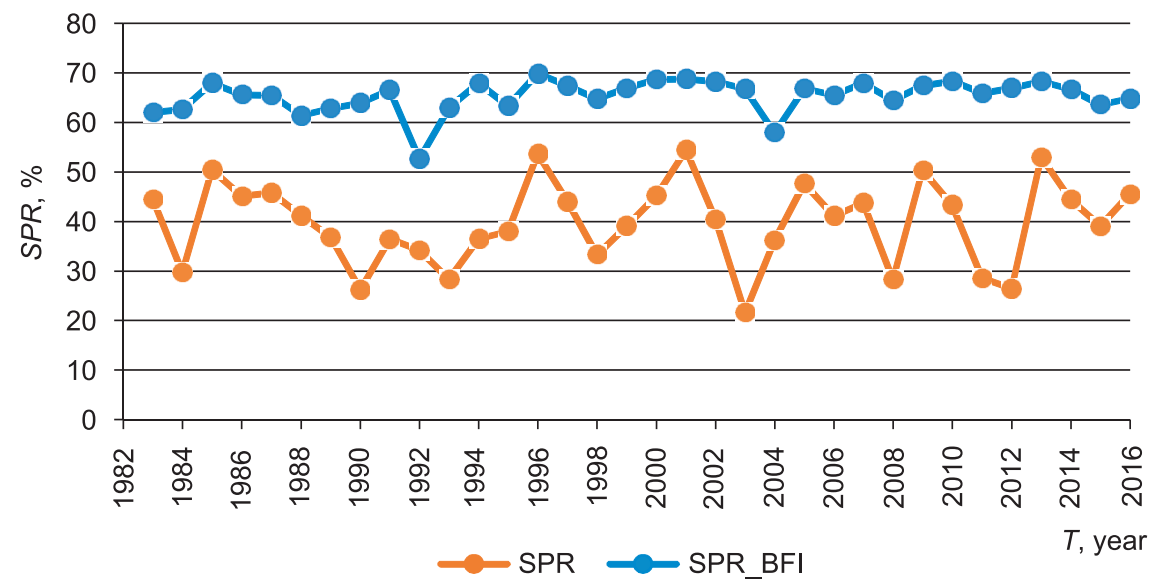

Fig. 7. Values of the SPR indicator calculated using formula (3) and those calculated using formula (4) based on the BFI determined for Wieprzówka river catchment to the Rudze water-gauge cross-section in the period 1983-2016. 
in the Wisła river catchment, and clearly differ from the other studied catchments. The second catchment with the lowest rainfall is the Wieprzówka river catchment, characterized by the lowest runoff in the analysed period. In the most urbanized catchment area, i.e. Biała river catchment, the most irregular and in most cases the highest runoff occurs. In individual cases, a higher runoff is recorded from the analysed mountain catchments.

In addition, for the water gauge of each catchment area, two floods from the summer period were analysed, which in terms of maximum flow in the period
1981-2017 were the largest and met the criterion of modal (single-peaked) floods. For all 4 catchment areas, these are floods registered in 1991 and 2010.

Each of the registered hydrographs was transformed into a unified hydrograph in accordance with the accepted method proposed by Archer (Archer et al., 2000). In order to assess the impact of forest and urbanization on the runoff from the catchment area for a single flood, the registered hydrographs for both adopted periods were compared with each other. Figures 8, 9, 10 and 11 show the registered maximum flow hydrographs.

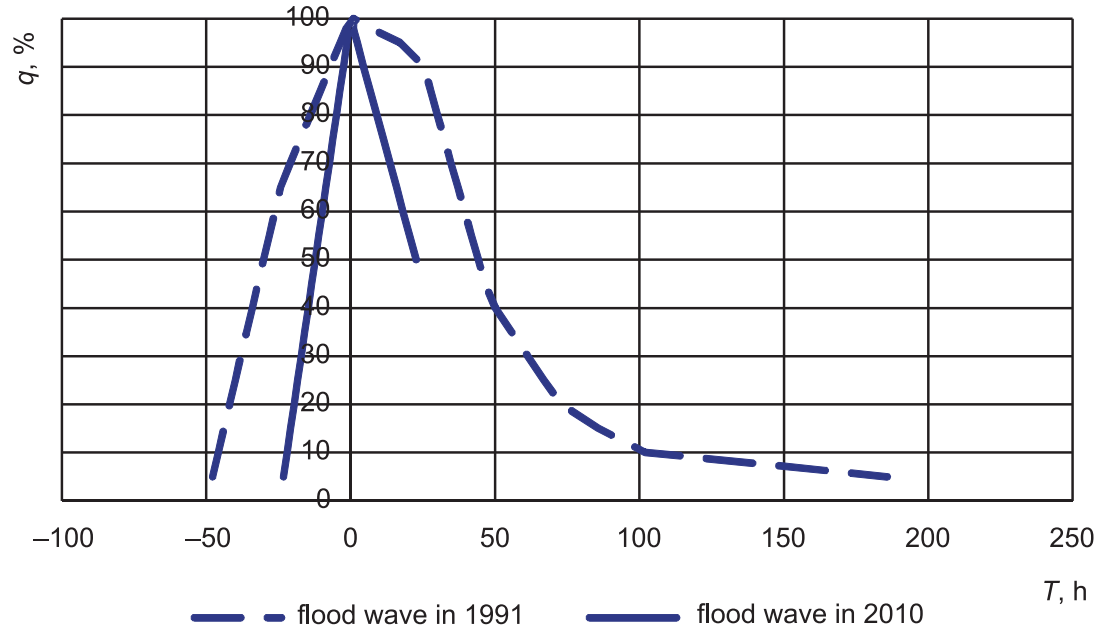

Fig. 8. Maximum hydrographs in Biała river catchment in 1991 and in 2010

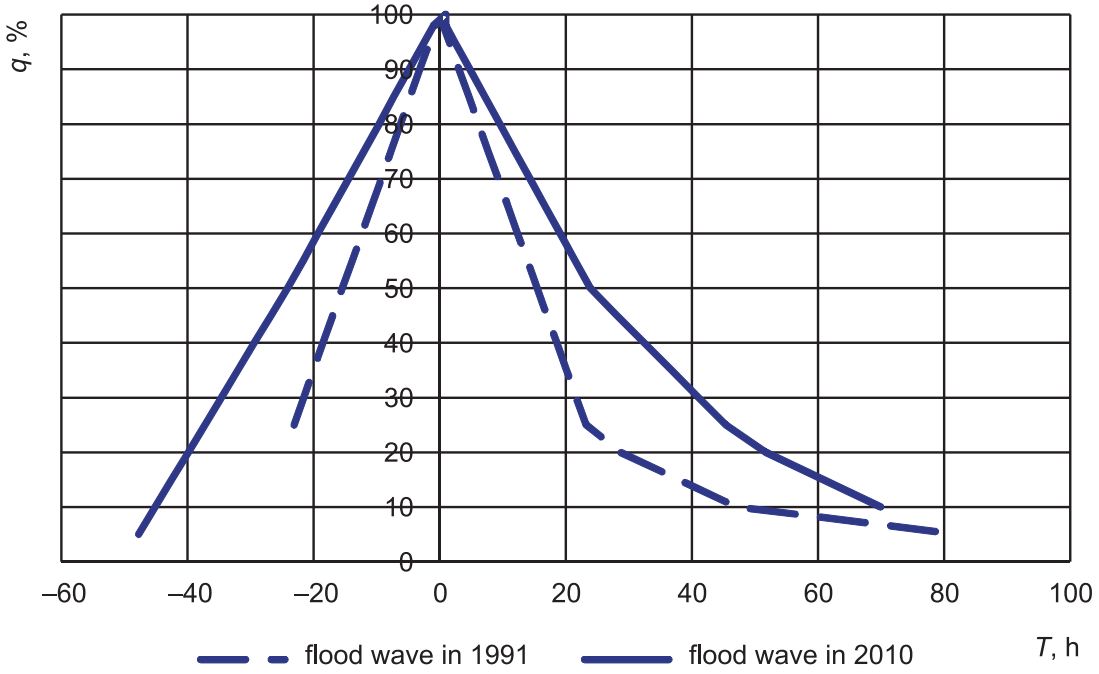

Fig. 9. Maximum hydrographs in Wieprzówka river catchment in 1991 and in 2010 


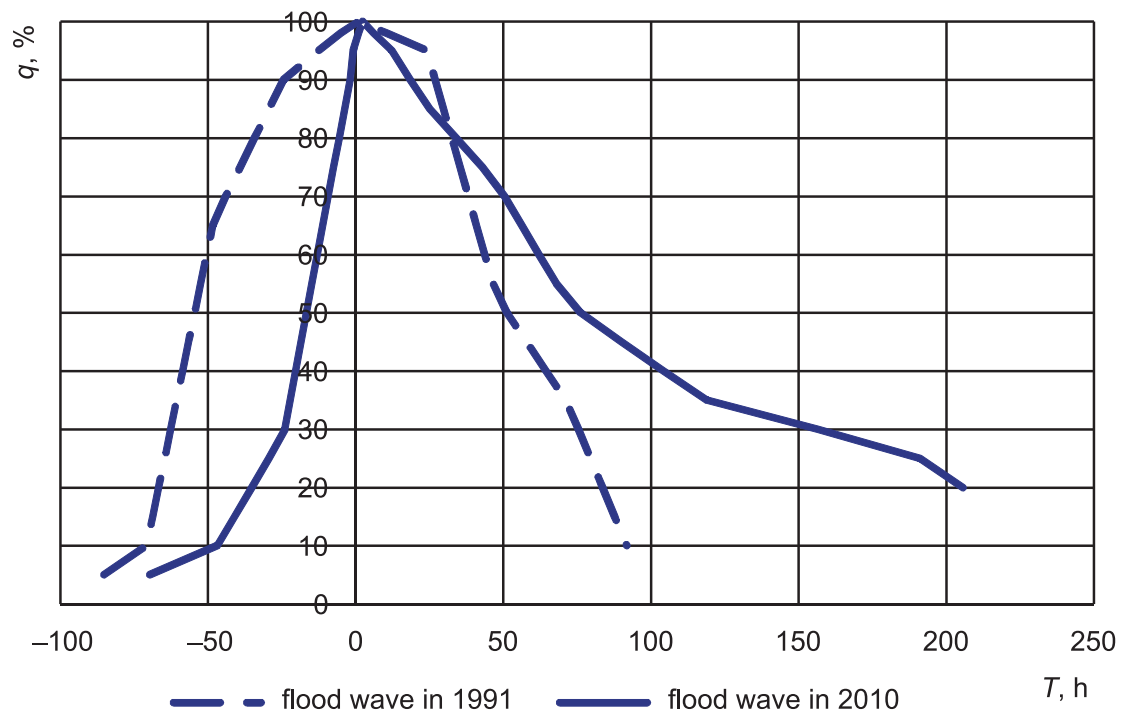

Fig. 10. Maximum hydrographs in Wisła river catchment in 1991 and in 2010

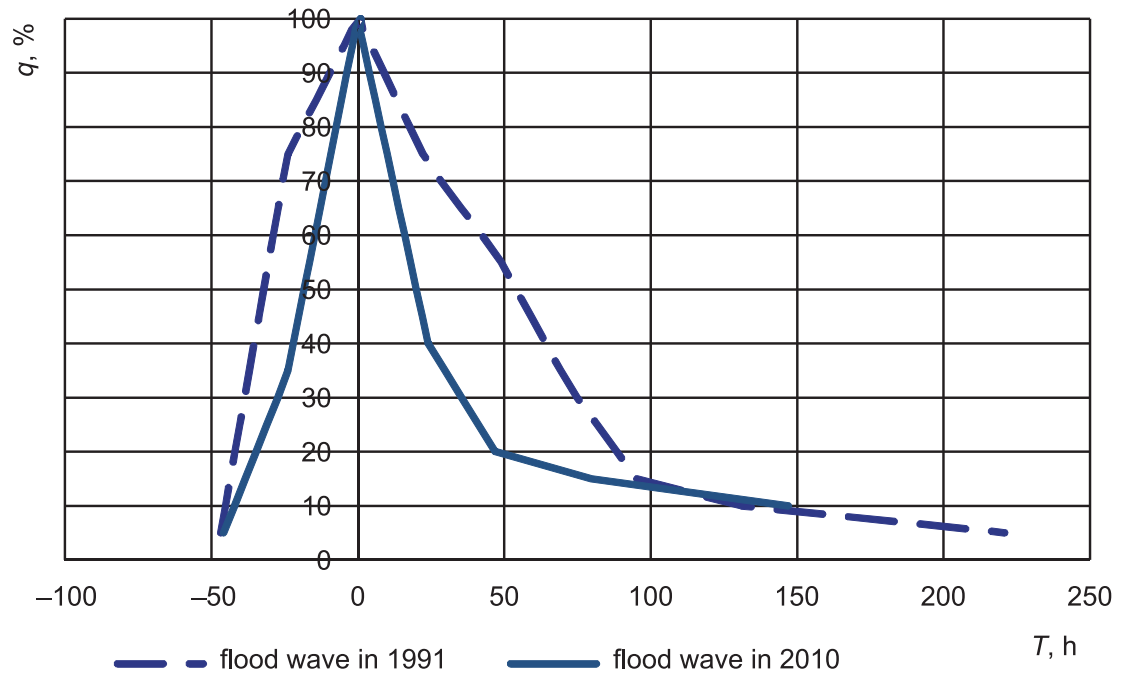

Fig. 11. Maximum hydrographs in Bystra river catchment in 1991 and in 2010

For each of the eight hydrographs obtained, the time to peak, lag time, and hydrograph volume were determined. The parameters were determined for the hydrograph value, for the flows above the hydrographs width $W_{50}$ and $W_{75}$, and the obtained results are presented in Table 5.

Based on the calculations made, the maximum hydrographs were the largest in the Biała river catchment.
This is liked to the high rainfall that occurred at the time in question, as well as to the sealing of the catchment. Higher sums of precipitation were recorded in the Wisła river catchment. The distribution of precipitation and the precipitation totals strongly influence the hydrograph volume, as well as the time to peak and lag time.

Variability of flow during the flood hydrograph from 1991, in the Wisła river catchment, has a completely 
Table 5. Parameters of the maximum flood hydrographs in 1991 and 2010 for selected water-gauge cross-sections and for the volume above the hydrograph width $W_{50}$

\begin{tabular}{|c|c|c|c|c|c|}
\hline \multirow[b]{2}{*}{ Year } & \multirow[b]{2}{*}{ Catchment } & \multicolumn{4}{|c|}{ Parameters of maximum hydrographs } \\
\hline & & $\begin{array}{c}\text { Time to } \\
\text { peak } W_{50} \\
{[\mathrm{~h}]}\end{array}$ & $\begin{array}{c}\text { Lag time } \\
W_{50} \\
{[\mathrm{~h}]}\end{array}$ & $\begin{array}{l}W_{75} \\
{[\mathrm{~h}]}\end{array}$ & $\begin{array}{c}\text { hydrograph } \\
\text { volume } \\
{\left[10^{6} \mathrm{~m}^{3}\right]}\end{array}$ \\
\hline \multirow{4}{*}{1991} & Biała & 47.74 & 185.83 & 49.88 & 5.11 \\
\hline & Wieprzówka & 23.06 & 82.23 & 15.43 & 1.47 \\
\hline & Wisła & 85.09 & 91.94 & 74.47 & 3.05 \\
\hline & Bystra & 46.82 & 220.80 & 45.98 & 1.44 \\
\hline \multirow{4}{*}{2010} & Biała & 23.15 & 22.73 & 17.46 & 9.08 \\
\hline & Wieprzówka & 47.68 & 69.92 & 23.98 & 5.68 \\
\hline & Wisła & 69.57 & 205.66 & 43.23 & 2.02 \\
\hline & Bystra & 45.79 & 146.94 & 19.16 & 1.06 \\
\hline
\end{tabular}

Table 6. Precipitation total and $S P R-W_{50}$ and $S P R-W_{75}$ runoff indices for 1991 and 2010 hydrographs, for the selected catchments

\begin{tabular}{|c|c|c|c|c|c|}
\hline Year & Catchment & $\begin{array}{c}\text { Precipi- } \\
\text { tation } \\
\text { total } \\
{[\mathrm{mm}]}\end{array}$ & $\underset{\left[\mathrm{m}^{3} \cdot \mathrm{s}^{-1}\right]}{Q_{\max }}$ & $\begin{array}{c}S P R-W_{50} \\
{[\%]}\end{array}$ & $\begin{array}{c}S P R-W_{75} \\
{[\%]}\end{array}$ \\
\hline \multirow{4}{*}{1991} & Biała & 166.8 & 59.8 & 26 & 8.8 \\
\hline & Wieprzówka & 59.5 & 50.6 & 16.3 & 4,2 \\
\hline & Wisła & 206.8 & 24 & 27 & 9,6 \\
\hline & Bystra & 146.4 & 17.8 & 20.4 & 5.2 \\
\hline \multirow{4}{*}{2010} & Biała & 371.7 & 286 & 20.7 & 5.2 \\
\hline & Wieprzówka & 232.8 & 131 & 16.1 & 4 \\
\hline & Wisła & 332.8 & 25.8 & 11.1 & 2.6 \\
\hline & Bystra & 165.8 & 30.2 & 13.3 & 3.4 \\
\hline
\end{tabular}

different course than the other flow hydrographs. The hydrograph volume above the $W_{75}$ hydrograph width is the highest value of all the catchment areas analysed, suggesting a very high surface runoff in that catchment.

\section{DISCUSSION AND CONCLUSIONS}

The basic SPR indicator is used in hydrology to assess the runoff height from a catchment area, based on recorded precipitation. In the catchments adopted for analysis, the data makes it impossible to determine this indicator for the Biała and Bystra river catchments. This is most likely due to the low density of precipitation monitoring networks in mountainous and foothill areas. For the other two catchments - of Wisła and Wieprzówka rivers - the SPR does not show any significant changes. In the Wieprzówka river catchment, the increase in sealed area in the period of 1990-2012 is balanced by the increment of forest area. In the Wisła river catchment, in respect to sealed areas, the data did not show an increase, whereas forest cover increased slightly.

For the other two catchment areas, although the SPR has decreased in recent years, the values of that ratio as well as the trend indicate the unreliability of the calculated values. An attempt to calculate the SPR indicator using the indirect method that applies formula (4), taking into account the BFI index, should also be considered unreliable. A comparison of the obtained SPR values with the values obtained by direct comparison of the runoff with precipitation demonstrated that formula (4) was not adapted to regional conditions. This formula requires that the results it produces should be analysed in terms of computational correctness for the entire upper Wisła region.

An analysis of the annual runoff totals over 37 years from 1981 to 2017 in the catchment area of the Rudze and Czechowice-Bestwin water-gauge cross-section shows clearly higher sums of annual runoff in the heavily built-up Biała river catchment. In the discussed multiannual period, the average annual runoff from the Wieprzówka river catchment - where built-up areas are three times smaller - is $60 \%$ lower than from the Biała river catchment. The average annual rainfall in the discussed multiannual period is $89 \mathrm{~mm}$ lower in the catchment area up to the Rudze water-gauge cross-section, which suggests the possibility of greater influence on the runoff pattern of other factors, such as built-up development, and parameters of individual hydrographs. The size of forest areas is almost identical in both catchments; therefore it is un- 
likely that this has much impact in this case. In the Wieprzówka river basin, the annual runoff is the most regular. A characteristic feature is also a very even ratio of the hydrograph volume to the sum of precipitation. Both in 1991 and 2010 the ratio of the volume of the hydrograph above the $W_{50}$ hydrograph width to the sum of precipitation is $16 \%$, and the ratio of the volume of the hydrograph above the $W_{75}$ hydrograph width is $40 \%$ (in 1991) and $42 \%$ (in 2010), despite a significant difference in the total amount of precipitation that occurred at that time. The average annual ratio of runoff to the precipitation total from the multiannual period in the catchment is only $40 \%$, with a value of $76 \%$ for the Biała river catchment. A clear correlation between the amount of precipitation and the size of the runoff as well as the parameters of a single hydrograph remains the characteristic feature of the Biała river catchment. An increase in precipitation results in an immediate response of the catchment area - namely, it results in increased runoff, an increased volume of the hydrograph, and a shorter time to peak, and lag time of the hydrograph.

When comparing the annual runoff and annual precipitation in the two analysed mountain catchments, we have concluded that in the Bystra river catchment, the average sum of the annual runoff from the multiannual period is about $6 \%$ lower than for the Wisła river catchment, with a large rainfall difference of about $36 \%$.

Most of the published results concern the impact of forest cover on the runoff from small experimental catchments with an area below $10 \mathrm{~km}^{2}$. Based on the conducted experimental studies (Guillemette et al., 2005), the author determined a clear trend depending on the degree of deforestation and reduction of the maximum flow. Transferring these results to larger catchment areas is difficult, as the authors of the publication stated, and would require additional analysis including but not limited to the composition of tree stand. Grant et al. (2008) proposed an assessment of the impact of afforestation on the reduction of maximum flows based on the results obtained for small research catchments. They found that the flow reduction could be close to $30 \%$ for $100 \%$ forest cover, and they also found that as the catchment area increases, the impact of afforestation on the flow reduction decreases.
Experimental studies conducted for catchments with larger surface areas confirm the impact of forest cover size on the size of the runoff (Coutu and Vega, 2007). The authors studied the impact of forest cover changes on surface runoff in partial catchments with areas ranging from 0.5 to $50 \mathrm{~km}^{2}$. Studies have shown that an average reduction in forest cover of $17 \%$ in a $316 \mathrm{~km}^{2}$ catchment area affected the increase of su face runoff, by $12.15 \%$ on average. At the same time, the values for individual sub-catchments showed great variation.

The variable impact of forest cover on the size of the SPR runoff index was confirmed by Sriwongsitanon and Toesombat (2011), based on research carried out for 11 catchments with areas from 240 to $3858 \mathrm{~km}^{2}$. A higher degree of afforestation reduced the SPR runoff index in the event of small flood episodes, while for large flood events wooded areas increased the amount of retained water resources, which in turn resulted in an increased runoff.

The rate of development of forest cover for the investigated catchments using data from CLC1990 and CLC2012, similarly to the forest cover index, shows an upward trend, whereas for the Wisła river catchment to the Wisła water-gauge cross-section there is a slight decrease. This suggests a negative process of changes in afforestation carried out in the catchment area. The increase in afforestation area does not improve the retention of the catchment area.

Summing up, the analyses we have carried out did not show the impact of forest areas and sealed surfaces on the runoff from the catchment. The adopted SPR indicator proved to be ineffective as an impact determinant. In addition, determining the value of this indicator is extremely difficult, and it requires well-functioning hydro-meteorological monitoring.

Other indicators are used in hydrology, such as the aforementioned BFI, PROPWET and GLEMOK (Bayliss, 1999; Reed, 2007; Mills el al. 2014; Baziak et. al., 2019). The latter descriptors include reference evaporation from the catchment. Perhaps one of these indicators will clearly determine the correlation between the impact of sealed and forest surface changes on the runoff from the catchment. 


\section{REFERENCES}

Archer, D., Foster, M., Faulkner, D. Mawdsley, H. (2000). The synthesis of design flood hydrographs. Proc. Flooding: risks and reactions. CIWEM/ICE Conference, London, 45-57.

Baziak, B., Gądek, W., Szczepanek, R. (2019). GLEMOK - novel method for catchment moisture determination using high-resolution soil map. Applied Ecology and Environmental Research, 12667-12681, DOI 10.15666/ aeer/1706_1266712681

Bielecka, E., Ciołkosz, A. (2004). Land Cover Structure In Poland and its Changes in the Last Decade of 20 Century. Annals of Geomatics, II, 1, 81-88.

Bayliss, A. C. (1999). Catchment descriptors. Volume 5 of the Flood Estimation Handbook. Center for Ecology \& Hydrology.

Boorman, D.B., Hollist, J.M., Lilly, A. (1995). Report No. 126 Hydrology of soil types: a hydrologically-based classification of the soils of the United Kingdom. Institute of Hydrology.

Bossard, M., Feranec, J., Otahel, J. (2000). CORINE Land Cover Technical Guide - Addendum 2000, Technical report No 40, EEA.

CLC. (2019). http://clc.gios.gov.pl/

Coutu, G.W., Vega C. (2007). Impacts of land use changes on runoff generation in the east branch of the Brandy Wine Creek watershed using a gis-based hydrologic model, Middle States Geographer, 40, 142-149.

FREND. (1989). Flow Regimes from Experimental and Network Data. Wallingford, Institute of Hydrology, 1.

Gądek, W. (2012). Wyznaczanie wezbrań hipotetycznych metodą Politechniki Warszawskiej i metodą Politechniki Krakowskiej w zlewniach kontrolowanych. Cz. I. Opis metod. Czasopismo Techniczne. Z. Ś-2, 95-104.

Gądek, W., Środula, A. (2014). The evaluation of the design flood hydrographs determined with the Hydroproject method in the gauged catchments. Infrastructure and ecology of rural areas. IV/3, 1355-1366.

Gądek, W. (2014). Theoretical flood waves for non-gauged catchments (in polish). Hydrologia w inżynierii i gospodarce wodnej T.1. pod redakcją Banasik K., Hajduk L., Kaznowska E. Monografia Komitetu Gospodarki Wodnej PAN. Zeszyt XX. II Krajowy Kongres Hydrologiczny. $139-150$.

Gądek, W. (2015). Typowy hydrogram przepływu do wyznaczania wezbrań hipotetycznych. Woda-Środowisko-Obszary Wiejskie. 15, 4(52), 5-18.

Gądek, W., Tokarczyk, T. (2015). Determining hypothetical floods in the Odra basin by means of the Cracow method and by volume formula. Infrastructure and ecology of rural areas. IV/4, 1507-1519.

Gądek, W., Baziak, B., Tokarczyk, T. (2017). Nonparametric design hydrograph in the gauged cross sections of the Vistula and Odra basin. Meteorology Hydrology and Water Management. Research and Operational Applications. 5, 1, 53-61.

Grant, G. E., Lewis, S. L., Swanson, F. J., Cissel, J. H., McDonnell, J. J. (2008) Effects of Forest Practices on Peak Flows and Consequent Channel Response: A State-ofScience Report for Western Oregon and Washington, United States Department of Agriculture, General Technical Report, PNW-GTR-760, http://www.fs.fed.us/ pnw/pubs/pnw_gtr760.pdf

Gudowicz, J., Zwoliński, Z. (2017). Kształtowanie się odpływu rzecznego w dorzeczu Parsęty w świetle modelowania hydrologicznego. Przegląd Geograficzny, 89, 1, 45-66.

Guillemette, F., Plamondon, A.P., Prevost, M., Levesque, D. (2005). Rainfall generated stormflow response to clearcutting a boreal forest: peak flow comparison with 50 world-wide basin studies. Journal of Hydrology, 302, 137-153.

IMGW PIB (2019), https://dane.imgw.pl/

Kondracki, J. (2000). Geografia regionalna Polski. Warszawa: Wydawnictwo Naukowe PWN.

Lambor, J. (1965). Podstawy i zasady gospodarki wodnej. Warszawa: Wydawn. Komunikacji i Łączności.

Lewiński, S. (2007). Obiektowa klasyfikacja zdjęć satelitarnych jako metoda pozyskiwania Informacji o pokryciu i użytkowaniu ziemi. Instytut Geodezji i Kartografii, Seria monograficzna, 12.

Mills, P., Nicholson, O., Reed, D. (2014). Flood Studies Update. Technical Research Report. 4. Physical Catchment Descriptors.

Ministerstwo Środowiska. (2009). Aktualna sytuacja lasów Beskidu Sądeckiego i Żywieckiego na przykładzie nadleśnictw Wisła i Ujsoły.

MPHP. (2019) https://dane.gov.pl

Murphy, C, Cunnane, C., Das, S., Mandal, U. (2014). Flood Studies Update. Technical Research Report. Vol. II. Flood Frequency Estimation.

O'Connor, K., Goswami, M., Faulkner, D. (2014). Flood Studies Update. Technical Research Report. Vol. III. Hydrograph Analysis.

Osuch, B., Kowalik, P. (1998). Wpływ lasu na stosunki wodne w zlewni. Referaty i materiały pokonferencyjne Międzynarodowej Konferencji Naukowej Las i Woda. Kraków. 14-21.

Ozga-Zielińska, M., Brzeziński, J. (1997). Hydrologia stosowana. Warszawa: Wydaw. Naukowe PWN. 
Osuch, B., Gądek, W., Homa, A., Cebulska, M., Szczepanek, R. Hebda-Małocha, A. (2009). Methods of estimating the elements of water balance in a forested catchment basin. Journal of Water and Land Development, $13 a, 19-40$.

Pieńkos, K., Szujecki, A. (1998). Lasy i leśnictwo w warunkach niepewności. Referaty i materiały pokonferencyjne Międzynarodowej Konferencji Naukowej Las i Woda. Kraków. 22-31.

Reed, D. (2007). Flood Studies Update Work-Package 5.4. Report to OPW. PROPWET for Ireland: A dimensionless index of typical catchment wetness. Wallingford. pp. 30 .
Rozwałka, Z., Wiśniewski, S. (1998). Lasy wodochronne w zagospodarowaniu przestrzennym kraju. Referaty i materiały pokonferencyjne Międzynarodowej Konferencji Naukowej Las i Woda. Kraków. 117-124.

Sriwongsitanon, N, Taesombat, W. (2011). Effects of land cover on runoff coefficient. Journal of Hydrology, 410, 226-238.

Więzik, B. (1997). Wpływ zagospodarowania przestrzennego na hydrogram odpływu ze zlewni. Materiały z konferencji naukowo-technicznej. Bielsko-Biała.

Zevenbergen, C., Cashman, A., Evelpidou, N., Pasche, E., Garvin, S., Ashley, R. (2011). Urban Flood Management. CRC Press London

\section{OCENA WPŁYWU ZAGOSPODAROWANIA ZLEWNI NA ODPŁYW Z WYKORZYSTANIEM WSKAŹNIKA SPR}

\section{ABSTRAKT}

\section{Cel pracy}

Celem publikacji jest ocena wpływu obszarów leśnych oraz zurbanizowanych na przebieg odpływu rzecznego w wieloleciu wraz z analizą przebiegu hydrogramów w wybranych zlewniach dla regionu górnej Wisły.

\section{Materiat i metody}

Dla potrzeb przeprowadzonych analiz wykorzystano: - dane wektorowe z bazy Komputerowej Mapy Podziału Hydrograficznego Polski - MPHP, 2010 w skali 1:50 000 pozyskane z Krajowego Zarządu Gospodarki Wodnej (MPHP 2019); - dane hydrologiczne - baza danych Instytutu Meteorologii i Gospodarki Wodnej PIB (dobowe wartości przepływu) w 4 przekrojach wodowskazowych zlokalizowanych na rzece: Bystrej, Wiśle, Wieprzówce i Białej dla okresu pomiarowego1981-2017 r. (IMGW PIB, 2019); - dane meteorologiczne baza danych Instytutu Meteorologii i Gospodarki Wodnej PIB obejmujące sumy dobowe opadów dla stacji: Kamesznica, Wisła-Malinka, Wadowice, Gierałtowice, Straconka, Szczyrk i Mazańcowice dla okresu 1981-2017 r. (IMGW PIB, 2019); - zagospodarowanie i użytkowanie obszaru zlewni - dane wektorowe z baz CLC1990 oraz CLC2012 w skali 1:100 000 (CLC, 2019). Szczegółowej analizie poddano maksymalne hydrogramy zarejestrowane w roku 1991 i 2010. Zarejestrowane hydrogramy przepływu zostały przekształcone do zunifikowanej postaci hydrogramu zaproponowanej przez Archera (Archer et al., 2000; Gądek, 2017). Na podstawie danych został określony wskaźnik odpływu standard percentage runoff SPR oraz przeprowadzono ocenę formuły umożliwiającej obliczenie wskaźnika SPR na podstawie base flow index BFI.

\section{Wyniki i wnioski}

Uzyskane wyniki przedstawiono na rysunkach oraz w tabelkach. Przeprowadzone analizy nie wykazały wpływu powierzchni zalesionych i szczelnych na odpływ ze zlewni. Przyjęty wskaźnik SPR jako identyfikator wpływu okazał się mało skuteczny. Dodatkowo wyznaczenie wartości tego wskaźnika jest bardzo trudne i wymaga dobrze funkcjonującego monitoringu hydrometeorologicznego.

Słowa kluczowe: wskaźnik lesistości, SPR, BFI, wyróżnik przepływu W50, wskaźnik urbanizacji 